\title{
EXAMINATION OF SELF-EFFICACY AND QUALITY OF LIFE OF PATIENTS WITH TYPE 2 DIABETES REGARDING DIABETES
}

\section{MANAGEMENT}

\author{
Ozlem CAGAN ${ }^{1}$, Gözde YESILAYDIN ${ }^{2}$, Bennur KOCA ${ }^{3}$
}

${ }^{1}$ Eskisehir Osmangazi University, Faculty of Health Sciences, Midwifery Department, Eskisehir, TURKEY
${ }^{2}$ Eskisehir Osmangazi University, Faculty of Health Sciences, Department of Health Management, Eskisehir, TURKEY
${ }^{3}$ Dokuz Eylul University, First and Emergency Aid Program, Vocational School of Health Services, Izmir, TURKEY

Address for Correspondence: Ozlem Cagan, E-mail: ozlemozcagan@gmail.com

Received: 17.03.2021; Accepted: 20.08.2021; Available Online Date: 20.09.2021

(C) Copyright 2021 by Dokuz Eylül University, Institute of Health Sciences - Available online at https://dergipark.org.tr/en/pub/jbachs

Cite this article as: Cagan O, Yesilaydin G, Koca B. Examination of Self-Efficacy and Quality of Life of Patients with Type 2 Diabetes Regarding Diabetes Management. J Basic Clin Health Sci 2021; 3: 43- 50.

\begin{abstract}
Purpose: Good self-management in patients with diabetes will help them to maintain their well-being and quality of life, and the control of risk factors will make it possible to manage disease symptoms and to prevent complications. This study was carried out to determine the self-efficacy levels of patients with type 2 diabetes regarding their care and the factors affecting them and to examine the relationship between patients' self-efficacy and quality of life.

Methods: This study used a cross-sectional design and was carried out with a total of 342 patients with type 2 diabetes. The Diabetes Management Self-Efficacy Scale (SES) was employed to evaluate diabetes self-efficacy levels of the patients, and the WHO Quality of Life Scale-Brief Form was used to evaluate their quality of life.

Results: The mean of the scores that the patients obtained from the SES scale was $64.16 \pm 12.09$. Diabetes self-efficacy was higher in patients who were married, were university graduates, had received training/information related to the disease, did not have any other chronic diseases, and did not exhibit any complications $(p<0.05)$. The quality of life of patients who did not exhibit any complications and were receiving oral antidiabetic medication was higher $(p<0.05)$.

Conclusions: A weak and positive correlation was found between the mean of the overall diabetes selfefficacy scale scores and the subscales of the quality of life scale. As the diabetes-related self-efficacy of the patients increased, their quality of life increased, as well.
\end{abstract}

Keywords: Type 2 diabetes, self-efficacy, self-management, quality of life

\section{INTRODUCTION}

Type 2 Diabetes Mellitus (T2DM) is an important public health problem affecting millions of people worldwide and its prevalence is increasing faster than predicted (1).

Diabetes is a chronic metabolic disease that develops due to insulin deficiency or defects in the effect of insulin, affects life expectancy and quality of life by causing organ failure and function losses due to its complications, and causes a social and economic burden due to the loss of labor (2).

According to the International Diabetes Federation (IDF), approximately 425 million people had diabetes as of the end of 2017 worldwide, and by 2045 this 
number is predicted to reach 630 million with a $48 \%$ increase. It is known that about $50 \%$ of people with diabetes are not aware of their illness and that threequarters of them live in low and middle-income countries (3).

Diabetes management does not only mean compliance with the recommended treatment but also requires some behavior changes in the individual's life. The concept of "self-efficacy" is shown as the key to achieving desired goals by making necessary behavior changes. "Self-efficacy" is a person's judgments, thoughts, and beliefs that they will successfully perform a behavior and that the behavior will lead to the desired outcome. Patients with diabetes who have high self-efficacy have been found to experience less emotional problems and have a higher quality of life (4).

Individuals with diabetes have to maintain planned care and complex treatment throughout their life. These treatment and care process causes patients to experience many restrictions and obligations. In addition to these, acute and chronic complications developing due to the disease decrease the quality of life. However, with a well-planned treatment, it is reported that the control of diabetes is achieved, complications decrease and that the quality of life of patients with diabetes increases (5).

In the literature, it is stated that high self-efficacy plays an important role in changing health behaviors and may positively affect the quality of life $(6,7)$. Studies have shown that individuals with higher selfefficacy levels are more effective in the disease process and in the management of their treatments (6). It is stated that individuals with high self-efficacy are more likely to engage in behaviors necessary to safely cope with various stress factors and to protect and maintain health (7). In order to improve the selfefficacy levels and quality of life of individuals with type 2 diabetes, it is important to determine the selfefficacy and quality of life levels and to provide appropriate services to increase them.

This study was planned to determine the self-efficacy levels of patients with type 2 diabetes regarding their care and the factors affecting them and to analyze the relationship between patients' self-efficacy and quality of life.

\section{MATERIAL AND METHODS}

\section{Participants}

The population of this cross-sectional study consisted of individuals who presented to State Hospital between September 2019 and December 2019, were aged 18 or older, had type 2 diabetes for one year or longer, and agreed to participate in the study. To determine adequate sample size $G^{*}$ Power 3.1 .9 was used. With the $95 \%$ power alpha and medium effect size $(p=0.3)$ the minimum sample size to be included in the study was calculated as $n=138$. A total of 342 people who agreed to participate in the study within the specified dates were included in the sample.

\section{Instruments}

The study data were collected using a structured questionnaire, which questioned the sociodemographic and diabetes-related data of the patients, the Diabetes Management Self-Efficacy Scale (SES), and the WHO Quality of Life Scale-Brief Form-Turkish Version (WHOQOL-BREF-TR).

\section{The Self-Efficacy Scale for Type 2 Diabetes}

The scale was developed by Van Der Bijl et al. (1999) based on the self-care activities that patients with diabetes needed to implement to manage diabetes (8). It consists of 20 five-point Likert-type questions with options ranging from 1 (no, definitely not) to 5 (yes, definitely). High scores obtained from the scale indicate a high level of self-efficacy. The Turkish validity and reliability study of the scale was conducted by Kara et al. (2006) and Cronbach's alpha was found to be 0.88 (9). In this study, Cronbach's alpha was found to be 0.915 .

\section{The WHO Quality of Life Scale-Brief Form-Turkish Version (WHOQOL-BREF-TR)}

This health-related quality of life scale was developed by WHO (10). The validity and reliability study of the scale was conducted by Eser et al. (11) The scale has two versions: long (WHOQOL-100) and short (WHOQOL-27). The brief form of the scale (WHOQOL-BREF) was used in this study. The scale measures physical, mental, social, and environmental well-being and consists of 26 questions. An extra question has been added to the Turkish version (question 27 is a national question). This question has been evaluated separately in the environmental domain and called as EnvironmentTR. The questions on the scale are rated between 1 and 5 points. Since each domain expresses the quality of life independently, the score of each domain is calculated between 4 and 20. As the score increases, the quality of life improves. 


\section{Ethical Considerations}

Ethical approval (25403353-050.E-37676), institutional permission, and consent of the participants were obtained for conducting the study.

\section{Data Analysis}

All analyses were performed using SPSS Statistics for version 21.0 program. The fit of the data to normal distribution was tested using the KolmogorovSmirnov test, and the data were found to not show a normal distribution. Also, the Mann-Whitney $U$ test, Kruskal-Wallis test, and Spearman's correlation analysis were employed for the statistical analyses. The significance level was accepted as $p<0.05$.

\section{RESULTS}

According to the findings, $61.4 \%$ of the participants were female, $76.9 \%$ were married, and $56.4 \%$ had primary school or lower education. The age of the participants ranged between 17 and 86 , and the mean age was $60.77 \pm 11.98$. Also, $81.3 \%$ of the participants were unemployed. Regarding the income status, $68.1 \%$ had income equal to expenses, and the income of $25.1 \%$ was less than their expenses. The duration of having diabetes was found to vary between 1 and 37 years, with an average of $12.07 \pm$ 7.78 years. Moreover, $67.3 \%$ of the participants had a family history of diabetes, and $71.3 \%$ had already received information about diabetes. The mean of the total self-efficacy scale scores was $64.16 \pm 12.09$. Table 1 presents the distribution of the means of the overall Diabetes Management Self-Efficacy Scale scores of the patients according to some of their socio-demographic and disease characteristics.

The quality of life of patients with diabetes participating in the study can be said to be at a moderate level in terms of all domains (Table 2).

Spearman's correlation analysis was conducted to examine the relationship between patients' diabetes self-efficacy and quality of life. The examination of the relationship between the subscales of the quality of life scale indicated that there was a strong and positive relationship between physical health and psychological subscales and a positive and very strong relationship between environment and environment-TR subscales. Also, there was a weak positive relationship between the overall diabetes self-efficacy scale and the subscales of the quality of life scale (Table 4).

\section{DISCUSSION}

Turkey ranks first in terms of diabetes prevalence in Europe and third place with its population with diabetes (12). According to the results of the Diabetes Epidemiology Study-II conducted in Turkey in 2010, the prevalence of diabetes in the population reached $13.7 \%$ in 12 years with a $90 \%$ increase. Also, the prevalence of impaired glucose tolerance (IGT) was reported to be $13.8 \%$ (13). In the present study, factors affecting the self-efficacy and quality of life of patients with type 2 diabetes were discussed in line with the literature.

The mean of the overall self-efficacy scores of the patients was determined to be high. The high level of self-efficacy is considered to show that individual diabetes management is good, while low levels are seen as a barrier to the management of diabetes (14). The mean diabetes self-efficacy scores obtained in the study were similar to those of the previous studies $(15,18)$.

In this study, no statistically significant difference was found between the sex of patients with diabetes and their diabetes self-efficacy scores. This finding was consistent with previous studies $(19,20)$.

A statistically significant difference was found between the education level and self-efficacy level of individuals in the study. The self-efficacy level of university graduates was higher than that of primary school graduates. As the education level increases, adaptation to the disease and fulfillment of the requirements of the disease are an expected result.

The self-efficacy levels of married people in our study were found to be significantly high. Similarly, the selfefficacy levels of the married people were higher in the study of Özdemir et al (21). This may be related to the support that married patients receive from their spouse in self-care.

In our study, the self-efficacy scores of those who received diabetes training were found to be significantly higher. In previous studies, the opinion that diabetes treatment was related to lifestyle changes more rather than healthcare services provided was prevalent $(22,23)$. For this reason, in clinical practices, planned training that strengthens the belief that patients are the main manager of their health and promotes health-related behavior changes has come to the fore (24). Research has shown that 
Table 1. Comparison of the means of the overall Diabetes Management Self-Efficacy Scale scores of the patients according to some of their socio-demographic and disease characteristics

\begin{tabular}{|c|c|c|c|c|}
\hline & Median & (Min.-Max.) & Z/KW & $\mathbf{p}$ \\
\hline \multicolumn{5}{|l|}{ Sex } \\
\hline Female (n: 210) & 64.00 & $(36-90)$ & \multirow{2}{*}{$Z=-1.571$} & \multirow{2}{*}{$p=0.116$} \\
\hline Male (n: 132) & 65.00 & $(24-90)$ & & \\
\hline \multicolumn{5}{|l|}{ Age groups } \\
\hline$\leq 45(n: 34)$ & 69.50 & $(49-88)$ & \multirow{5}{*}{$K W=19.247$} & \multirow{5}{*}{$p=0.001$} \\
\hline $46-55$ (n: 69) & 65.00 & $(36-90)$ & & \\
\hline $56-65$ (n: 120) & 66.00 & $(37-90)$ & & \\
\hline $66-75$ (n: 82) & 64.00 & $(33-90)$ & & \\
\hline $76 \geq(\mathrm{n}: 37)^{\star}$ & 56.00 & $(24-83)$ & & \\
\hline \multicolumn{5}{|l|}{ Marital status } \\
\hline Married (n: 263) & 66.00 & $(33-90)$ & \multirow{2}{*}{$Z=-3.189$} & \multirow{2}{*}{$p=0.001$} \\
\hline Single (n: 79) & 59.00 & $(24-86)$ & & \\
\hline \multicolumn{5}{|l|}{ Level of education } \\
\hline$\leq$ Primary Sch. $(\mathrm{n}: 193)^{*}$ & 63.00 & $(24-90)$ & \multirow{4}{*}{$K W=11.736$} & \multirow{4}{*}{$p=0.008$} \\
\hline Secondary Sch.(n: 58) & 65.50 & $(37-90)$ & & \\
\hline High School (n: 45) & 68.00 & $(48-86)$ & & \\
\hline University $(\mathrm{n}: 46)^{*}$ & 67.50 & $(49-90)$ & & \\
\hline \multicolumn{5}{|l|}{ Employment } \\
\hline Employed (n: 64) & 66.50 & $(48-90)$ & \multirow{2}{*}{$Z=-1.882$} & \multirow{2}{*}{$p=0.060$} \\
\hline Unemployed (n: 278) & 64.00 & $(24-90)$ & & \\
\hline \multicolumn{5}{|c|}{ Duration of diabetes history (years) } \\
\hline$\leq 4(\mathrm{n}: 59)(1)$ & 66.00 & $(36-90)$ & \multirow{4}{*}{$\mathrm{KW}=7.487$} & \multirow{4}{*}{$p=0.058$} \\
\hline $5-12(n: 144)$ & 65.00 & $(24-90)$ & & \\
\hline $13-20(\mathrm{n}: 91)$ & 62.00 & $(33-90)$ & & \\
\hline $21 \geq(\mathrm{n}: 48)$ & 66.00 & $(42-90)$ & & \\
\hline \multicolumn{5}{|c|}{ Previous diabetes training/information } \\
\hline Yes (n: 244) & 66.00 & $(37-90)$ & \multirow{2}{*}{$Z=-3.555$} & \multirow{2}{*}{$p=0.000$} \\
\hline No (n: 98) & 61.00 & $(24-90)$ & & \\
\hline \multicolumn{5}{|l|}{ Co-morbid chronic diseases } \\
\hline Yes (n: 219) & 62.00 & $(24-90)$ & \multirow{2}{*}{$Z=-3.794$} & \multirow{2}{*}{$p=0.000$} \\
\hline No (n: 123) & 68.00 & $(36-90)$ & & \\
\hline \multicolumn{5}{|l|}{ Complications } \\
\hline Yes (n: 171) & 63.00 & $(24-90)$ & \multirow{2}{*}{$Z=-2.469$} & \multirow{2}{*}{$p=0.014$} \\
\hline No (n: 171) & 65.00 & $(36-90)$ & & \\
\hline \multicolumn{5}{|l|}{ Treatment methods used } \\
\hline Insulin treatment (n: 160) & 61.00 & $(36-90)$ & $7=-3913$ & $n=0,000$ \\
\hline Oral antidiabetic agents (n: 182) & 66.50 & $(24-90)$ & $\angle=-3.913$ & $p=0.000$ \\
\hline
\end{tabular}

*The group creating the difference

major complications occur as much as four times more in cases where individuals with diabetes are not trained (25).

In the present study, the self-efficacy of patients who did not have a chronic disease other than diabetes was found to be higher. This can be explained by the fact that patients focus on a single disease and that they develop self-efficacy regarding that disease only. High self-efficacy in patients with diabetes is the desired status to prevent complications that may occur in these patients. In our study, self-efficacy was found to be significantly higher in patients who did not exhibit any disease-specific complications. Wellplanned treatment and care are reported to achieve diabetes control and to reduce complications (5).

The patients receiving oral antidiabetic treatment had higher diabetes self-efficacy. Type of treatment may affect patients' disease management-related selfefficacy status and their well-being. The patients in the study group had a high level of adaptation to the disease. Therefore, they were using oral treatment because, thanks to their adaptation, the disease had not progressed much to make them use insulin treatment. 
Table 2. Distribution of the mean scores of individuals with type 2 diabetes obtained from the subscales of the Quality of Life Scale

\begin{tabular}{lllll} 
Life Quality Domains & Mean \pm sd & Minimum & Maximum & $\begin{array}{l}\text { Min.-max. scores that can } \\
\text { be obtained from the } \\
\text { subscales }\end{array}$ \\
\hline Physical Health & $14.04 \pm 2.98$ & 6.29 & 20.00 & $4-20$ \\
\hline Psychological & $14.37 \pm 2.74$ & 4.00 & 19.33 & $4-20$ \\
\hline Social Relationships & $13.49 \pm 3.04$ & 4.00 & 20.00 & $4-20$ \\
\hline Environment & $14.50 \pm 2.40$ & 5.00 & 19.50 & $4-20$ \\
\hline Environment -TR & $14.40 \pm 2.23$ & 6.67 & 19.56 & $4-20$ \\
\hline
\end{tabular}

Table 3. Comparison of subscale scores of the Quality of Life Scale according to some disease-related data

\begin{tabular}{|c|c|c|c|c|c|}
\hline & \multicolumn{5}{|c|}{ Quality of Life Scale (WHOQOL-BREF-TR) } \\
\hline & $\begin{array}{l}\text { Physical } \\
\text { Health }\end{array}$ & Psychological & $\begin{array}{l}\text { Social } \\
\text { Relationships }\end{array}$ & Environment & Environment-TR \\
\hline & $\begin{array}{l}\text { Median } \\
\text { (Min.-Max.) }\end{array}$ & $\begin{array}{l}\text { Median } \\
\text { (Min.-Max.) }\end{array}$ & $\begin{array}{l}\text { Median } \\
\text { (Min.-Max.) }\end{array}$ & $\begin{array}{l}\text { Median } \\
\text { (Min.-Max.) }\end{array}$ & $\begin{array}{l}\text { Median } \\
\text { (Min.-Max.) }\end{array}$ \\
\hline \multicolumn{6}{|c|}{ Duration of diabetes history (years) } \\
\hline$\leq 4(\mathrm{n}: 59)^{*}$ & $\begin{array}{l}14.86 \\
(6.29-20.00)\end{array}$ & $\begin{array}{l}15.33 \\
(6.00-19.33)\end{array}$ & $\begin{array}{l}14.67 \\
(6.67-20.00)\end{array}$ & $\begin{array}{l}15.00 \\
(8.00-19.00)\end{array}$ & $\begin{array}{l}14.67 \\
(8.44-19.11)\end{array}$ \\
\hline 5-12 (n: 144) & $\begin{array}{l}13.71 \\
(6.86-20.00)\end{array}$ & $\begin{array}{l}14.67 \\
(4.00-19.33)\end{array}$ & $\begin{array}{l}13.33 \\
(4.00-20.00)\end{array}$ & $\begin{array}{l}15.00 \\
(5.00-19.50)\end{array}$ & $\begin{array}{l}14.67 \\
(6.67-19.11)\end{array}$ \\
\hline $13-20(n: 91)$ & $\begin{array}{l}13.71 \\
(6.86-20.00)\end{array}$ & $\begin{array}{l}14.00 \\
(7.33-19.33)\end{array}$ & $\begin{array}{l}12.00 \\
(4.00-20.00)\end{array}$ & $\begin{array}{l}14.50 \\
(6.50-19.50)\end{array}$ & $\begin{array}{l}14.22 \\
(7.56-19.56)\end{array}$ \\
\hline \multirow[t]{2}{*}{$21 \geq(\mathrm{n}: 48)^{\star}$} & $\begin{array}{l}13.71 \\
(7.43-19.43)\end{array}$ & $\begin{array}{l}14.00 \\
(9.33-18.67)\end{array}$ & $\begin{array}{l}12.00 \\
(6.67-18.67)\end{array}$ & $\begin{array}{l}14.50 \\
(10.50-18.00)\end{array}$ & $\begin{array}{l}14.22 \\
(11.11-18.22)\end{array}$ \\
\hline & $\begin{array}{l}K W=9.140 \\
p=0.027\end{array}$ & $\begin{array}{l}K W=8.324 \\
p=0.040\end{array}$ & $\begin{array}{l}K W=10.24 \\
p=0.017\end{array}$ & $\begin{array}{l}K W=1.343 \\
p=0.719\end{array}$ & $\begin{array}{l}K W=1.056 \\
p=0.788\end{array}$ \\
\hline \multicolumn{6}{|c|}{ Co-morbid chronic disease } \\
\hline Yes (n: 219) & $\begin{array}{l}13.71 \\
(6.86-20.00)\end{array}$ & $\begin{array}{l}14.00 \\
(4.00-19.33)\end{array}$ & $\begin{array}{l}13.33 \\
(4.00-20.00)\end{array}$ & $\begin{array}{l}14.50 \\
(5.00-19.50)\end{array}$ & $\begin{array}{l}14.22 \\
(6.67-19.56)\end{array}$ \\
\hline \multirow[t]{2}{*}{ No (n: 123) } & $\begin{array}{l}15.43 \\
(6.29-20.00)\end{array}$ & $\begin{array}{l}15.33 \\
(6.00-19.33)\end{array}$ & $\begin{array}{l}14.67 \\
(6.67-20.00)\end{array}$ & $\begin{array}{l}14.50 \\
(8.00-19.00)\end{array}$ & $\begin{array}{l}14.67 \\
(8.44-19.11)\end{array}$ \\
\hline & $\begin{array}{l}Z=-5.417 \\
p=0.000\end{array}$ & $\begin{array}{l}Z=-4.268 \\
p=0.000\end{array}$ & $\begin{array}{l}Z=-4.467 \\
p=0.000\end{array}$ & $\begin{array}{l}Z=-0.720 \\
p=0.471\end{array}$ & $\begin{array}{l}Z=-1.060 \\
p=0.289\end{array}$ \\
\hline \multicolumn{6}{|l|}{ Complications } \\
\hline Yes (n: 171) & $\begin{array}{l}13.14 \\
(6.86-20.00)\end{array}$ & $\begin{array}{l}13.33 \\
(4.00-19.33)\end{array}$ & $\begin{array}{l}13.33 \\
(4.00-20.00)\end{array}$ & $\begin{array}{l}14.00 \\
(5.00-19.50)\end{array}$ & $\begin{array}{l}14.22 \\
(6.67-19.56)\end{array}$ \\
\hline \multirow[t]{2}{*}{ No (n: 171) } & $\begin{array}{l}15.43 \\
(6.29-20.00)\end{array}$ & $\begin{array}{l}15.33 \\
(6.00-19.33)\end{array}$ & $\begin{array}{l}14.67 \\
(6.67-20.00)\end{array}$ & $\begin{array}{l}15.00 \\
(8.00-19.50)\end{array}$ & $\begin{array}{l}15.11 \\
(8.44-19.11)\end{array}$ \\
\hline & $\begin{array}{l}Z=-5.918 \\
p=0.000\end{array}$ & $\begin{array}{l}Z=-5.065 ; \\
p=0.000\end{array}$ & $\begin{array}{l}Z=-2.649 \\
p=0.008\end{array}$ & $\begin{array}{l}Z=-2.459 \\
p=0.014\end{array}$ & $\begin{array}{l}Z=-2.786 \\
p=0.005\end{array}$ \\
\hline \multicolumn{6}{|c|}{ Treatment methods used } \\
\hline $\begin{array}{l}\text { Insulin treatment } \\
(\mathrm{n}: 160)\end{array}$ & $\begin{array}{l}13.14 \\
(6.29-20.00)\end{array}$ & $\begin{array}{l}14.00 \\
(4.00-19.33)\end{array}$ & $\begin{array}{l}13.33 \\
(4.00-20.00)\end{array}$ & $\begin{array}{l}14.00 \\
(6.50-19.50)\end{array}$ & $\begin{array}{l}14.22 \\
(7.56-19.56)\end{array}$ \\
\hline $\begin{array}{l}\text { Oral antidiabetic } \\
\text { agents (n: 182) }\end{array}$ & $\begin{array}{l}14.86 \\
(7.43-20.00)\end{array}$ & $\begin{array}{l}15.33 \\
(4.00-19.33)\end{array}$ & $\begin{array}{l}13.33 \\
(4.00-20.00)\end{array}$ & $\begin{array}{l}15.00 \\
(5.00-19.50)\end{array}$ & $\begin{array}{l}15.11 \\
(6.67-19.56)\end{array}$ \\
\hline & $\begin{array}{l}Z=-3.759 \\
p=0.000\end{array}$ & $\begin{array}{l}Z=-3.453 \\
p=0.001\end{array}$ & $\begin{array}{l}Z=-3.526 \\
p=0.000\end{array}$ & $\begin{array}{l}Z=-3.457 \\
p=0.001\end{array}$ & $\begin{array}{l}Z=-3.378 \\
p=0.001\end{array}$ \\
\hline
\end{tabular}

${ }^{*}$ The group creating the difference 
Table 4. Correlation analysis between patients' diabetes self-efficacy and quality of life

\begin{tabular}{|c|c|c|c|c|c|c|c|}
\hline & & 1 & 2 & 3 & 4 & 5 & 6 \\
\hline \multirow{2}{*}{ Total Diabetes Self-Efficacy (1) } & $\mathbf{r}$ & 1.00 & $0.414^{\star \star}$ & $0.461^{\star \star}$ & $0.287^{* *}$ & $0.389^{* *}$ & $0.398^{* *}$ \\
\hline & $\mathbf{p}$ & . & 0.000 & 0.000 & 0.000 & 0.000 & 0.000 \\
\hline \multirow{2}{*}{ Physical Health Domain (2) } & $\mathbf{r}$ & & 1.00 & $0.691^{* *}$ & $0.388^{* *}$ & $0.567^{* *}$ & $0.593^{* *}$ \\
\hline & $\mathbf{p}$ & & & 0.000 & 0.000 & 0.000 & 0.000 \\
\hline \multirow{2}{*}{ Psychological Domain (3) } & $\mathbf{r}$ & & & 1.00 & $0.431^{* *}$ & $0.547^{\star *}$ & $0.579^{* *}$ \\
\hline & $\mathbf{p}$ & & & . & 0.000 & 0.000 & 0.000 \\
\hline \multirow{2}{*}{ Social Relationships Domain (4) } & $\mathbf{r}$ & & & & 1.00 & $0.484^{\star *}$ & $0.510^{\star *}$ \\
\hline & $\mathbf{p}$ & & & & . & 0.000 & 0.000 \\
\hline \multirow{2}{*}{ Environment Domain (5) } & $\mathbf{r}$ & & & & & 1.00 & $0.980^{* *}$ \\
\hline & $\mathbf{p}$ & & & & & . & 0.000 \\
\hline \multirow{2}{*}{ Environment -TR Domain (6) } & $\mathbf{r}$ & & & & & & 1.00 \\
\hline & $\mathbf{p}$ & & & & & & . \\
\hline
\end{tabular}

${ }^{* *}$ The correlation was significant at 0.01

The quality of life of patients with diabetes participating in the study can be said to be at a moderate level in terms of all subscales. The quality of life of individuals with chronic disease can be impaired as a result of many symptoms and complications caused by the disease (26). Studies indicate that the mean quality of life scores of individuals with a chronic disease is lower than those without a chronic disease $(27,28)$.

In our study, the quality of life of patients who had diabetes for 4 years or less was found to be higher than those who had the disease longer. According to Çıtıl et al (2010), who examined the effect of medical and social factors on the quality of life in patients with diabetes, the quality of life decreases as the duration of the disease gets longer (29). The findings of our study were found to support these findings.

Moreover, the quality of life of patients who used oral antidiabetic medication was found to be significantly higher. In the literature, the quality of life of patients applying especially insulin treatment has been reported to decrease (30).

Diabetes affects the quality of life, and especially the development of complications is stated to deteriorate it (31). Similar to the findings in the literature, the quality of life of patients who had complications was found to be lower in our study.

A weak and positive relationship was found between the total score of diabetes self-efficacy scale and the subscales of the quality-of-life scale. Accordingly, it can be said that as the self-efficacy of patients increases, their quality-of-life increases, as well.

\section{CONCLUSION}

The findings of the present study indicated that patients' self-efficacy levels were high, and that patient characteristics such as age, marital status, training about diabetes, presence of accompanying chronic diseases, development of complications, and treatment method affected the self-efficacy level. A relationship was found between the self-efficacy scores and the quality of life of patients. In line with these results, it may be recommended to plan individual and group training programs to increase self-care and self-efficacy levels of patients and to help them cope with diabetes and improve selfmanagement of diabetes.

Author contribution: ÖÇ: Conception, design, literature review, data collection, data processing, writing, critical review GY: Design, data collection, analysis BK: Literature review and interpretation, editing.

Conflict of interests: The authors declare no conflict of interest. Ethical Approval: This study was approved by Eskisehir Osmangazi University Social and Human Sciences Scientific Research and Publication Ethics Committee (Date: 03.04.2018 and issue: 25403353-050.E-37676).

Informed Consent: Informed consent was signed by the patients. Funding: The authors declared that this study has received no financial support.

Peer-review: Externally peer-reviewed.

\section{REFERENCES}

1. Guariguata L, Whiting DR, Hambleton I, Linnenkamp U, Shaw JE. Global estimates of diabetes prevalence for 2013 and projections for 2035. Diabetes Res Clin Pract 2014;103(2): 13749.

2. Olgun N. Diyabet (Tip II) ve Bakım. (Ed: Durna Z). In: Kronik Hastalıklar ve Bakım. Istanbul: Nobel Tıp Kitabevleri 2012: 291-332

3. International Diabetes Federation. Diabetes atlas. 8th edition. Available From: http://www.diabetesatlas.org__[Verified 25 December 2019]. 
4. Zhu Y, Fish AF, Li F, Liu L, Lou Q. Psychosocial factors not metabolic control impact the quality of life among patients with type 2 diabetes in China. Acta Diabetol 2016; 53(4): 535-41.

5. Funnell MM, Brown TL, Childs BP, Haas LB, Hosey GM, Jensen B et al. National standarts for diabetes self management education. Diabetes Care. 2009; 32 (1): 587-94.

6. Su X, Qin F, Zhen L, Ye X, Kuang Y, Zhu M, Yin $X$, Wang $H$. Self-efficacy and Associated Factors in Patients With Temporary Ostomies, Journal of Wound, Ostomy and Continence Nursing. 2016; 43(6): 623-629.

7. Su, X, Zhen, L, Zhu, M, Kuang, Y, Qin, F, Ye, X, Yin, $X$, Wang, $H$, Determinants of self-efficacy and quality of life in patients with temporary enterostomy: a cross-sectional survey, Journal of Clinical Nursing. 2017; 26(3-4): 477-484.

8. Bijl JV, Poelgeest-Eeltink AV, Shortridge-Baggett L. The psychometric properties of the diabetes management self-efficacy scale for patients with type 2 diabetes mellitus. J Adv Nurs 1999; 30: 352-359.

9. Kara M, Van der Bijl JJ, Shortridge-Baggett LM, Asti T, Erguney S. Cross-cultural adaptation of the Diabetes Management Self-Efficacy Scale for patients with type 2 diabetes mellitus: scale development. Int J Nurs Stud, 2006; 43(5): 61121.

10. World Health Organization. WHOQOL-BREF introduction, administiration, scoring and generic version of the assessment. Geneva: Programme on Mental Health, Field Trial Version;1996.

11. Eser E, Fidaner H, Fidaner C, Eser SY, Elbi H. ve Göker E. Psychometric properties of tlte WHOQOL-100 and WHOOOLBREF. 3P Dergisi 199; 7(2): 23-40.

12. International Diabetes Federation. Diabetes atlas. 9th edition. Available from: https://www.diabetesatlas.

org/upload/resources/2019/IDF_Atlas_9th_Editio n_2019. pdf [Verified 25 December 2019].

13. Satman I, Omer B, Tutuncu Y, Kalaca S, Gedik $\mathrm{S}$, Dinccag $\mathrm{N}$ et al. Twelve-year trends in the prevalence and risk factors of diabetes and prediabetes in Turkish adults. Eur $\mathrm{J}$ Epidemiol 2013; 28: 169-80.

14. Glasgow RE, Tooberth DJ. Gilette CD. Psychosocial barriers to diabetes self management and quality of life. Diabetes Spectrum 2001;14(1): 33-41.
15. Wichit N, Mnatzaganian G, Courtney M, Schulz $P$, Johnson M. Randomized controlled trial of a family-orientedself-management program to improve self-efficacy, glycemic control and quality of life among Thaiindividuals with Type 2 diabetes. Diabetes Res Clin Pract 2017; 123: 3748.

16. Kav S, Yilmaz AA, Bulut Y, Dogan N. Selfefficacy, depression and self-careactivities of people with type 2 diabetes in Turkey. Collegian 2017; (24): 27-35.

17. Sireci E, Karabulutlu EY. Diabetes mellitus type II patients' acceptance of illness and determination of self efficacy levels for their care. Journal of Anatolia Nursing and Health Sciences 2017; 20(1): 48-55.

18. Lin K, Park C, Li M, Wang X, Li X, Li W, Quinn L. Effects of depression, diabetes distress, diabetes self-efficacy, and diabetes self-management on glycemic control among Chinese population with type 2 diabetes mellitus. Diabetes Res Clin Pract 2017; 131: 179-186.

19. D'Souza MS, Karkada SN, Parahoo K, Venkatesaperumal R, Achora S, Cayaban ARR. Self-efficacy and self-care behaviours among adults with type 2 diabetes. Appl Nurs Res 2017; 36: $25-32$.

20. Tosun AS, Zincir $H$. The effect of a transtheoretical model-based motivational interview on self-efficacy, metabolic control, and health behaviour in adults with type 2 diabetes mellitus: A randomized controlled trial. Int J Nurs Pract 2019; 25 e12742: 1-12.

21. Ozdemir A, Kavak F, Gultekin A. Determining the self-efficacy perceived with social support in type II diabetes patients. Turkiye Klinikleri J Nurs Sci 2019;11(3): 305-12.

22. Mishali $M$, Omer $H$, Heymann AD. The importance of measuring self-efficacy in patients with diabetes. Fam Pract 2011; 28(1): 82-87.

23. Osborn CY, Egede LE. Validation of an information-motivation-behavioral skills model of diabetes self-care (IMB-DSC). Patient Educ and Couns 2010; 79(1): 49-54.

24. Kosti M, Kanakari M. Education and diabetes mellitus. Health Science Journal 2012; 6(4): 654662.

25. Funnell MM, Brown TL, Childs BP, Haas Hosey GM, Jensen B, Maryniuk $M$, et al. National standards for diabetes self-management education. Diabetes Care 2008; 31(1): 97- 104. 
26. Karakoç Kumsar A, Taşkın Yılmaz F. Overview of quality of life in chronic disease patients. ERÜ Sağlık Bilimleri Fakültesi Dergisi 2014; 2(2): 6270.

27. Prasanna Kumar HR, Mahesh MG, Menon VB, Srinath KM, Shashidhara KC, Ashos P. Patient self-reported quality of life assessment in Type 2 diabetes mellitus: A pilot study. Niger J Clin Pract 2018; 21(3): 343-349.

28. Karyani AK, Rashidian A, Sefiddashti SE, Sari AA. Self-reported health-related quality of life (HRQoL) and factors affecting HRQoL among individuals with health insurance in Iran. Epidemiol Health 2016; 38: 1-8.

29. Cıtıl R, Günay O, Elmalı F, Oztürk Y. The effects of medical and social factors on the quality of life of diabetic patients. Erciyes Medical Journal 2010; 32(4): 253-64.

30. Altunoğu EG, Sarı Z, Erdenen F, Müderrisoğlu C, Ülgen E, Sarı M. The relationship of depression, anxiety and disability with $\mathrm{HbA}_{1 \mathrm{c}}$ and the duration of diabetes in patients with type 2 Diabetes Mellitus. Istanbul Med J, 2012; 13(3): 115-119.

31. Pouwer F, Hermanns N. Insulin therapy and quality of life. A review. Diabetes Metab Res Rev 2009; 25: 4-10. 